\title{
The Future Relations between the Majority and Minority Religious Groups, Viewed from Indonesian Contemporary Perspective: A Case Study of the Coexistence of Muslims and the Towani Tolotang in Amparita, South Sulawesi
}

\author{
HASSE JUBBA*, MUSTAQIM PABBAJAH, ZAINUDDIN H PRASODJO \& ZULI QODIR
}

\begin{abstract}
The topic of relations of several religious groups in the world from different perspectives has been a hot issue among researchers and stakeholders. This article addresses the future relations between the majority and minority religious groups, particularly a case study of Bugis Muslims and Bugis Hindus known as Towani Tolotang who live in a harmonious life in South Sulawesi seen from Indonesian contemporary perspective. The present article is based on our research conducted in 2017 and 2018. The results show that Muslim majority and Hindu minority have been living in a dynamic and harmonious life because they have shared similar Bugis cultural background and tradition. In addition, the honesty of Bugis Muslims towards Bugis Hindus has contributed to a conducive living atmosphere. In addition, the existence of equality for the socio-politico status and economic endeavour for the Muslim majority and Hindu minority has brought them into a good social life. So, both communities may enjoy a long period of peaceful and prosperous coexistence in Indonesian modern life.
\end{abstract}

Keywords: coexistence, interreligious relations, majority-minority relations, religion in Indonesia, Towani Tolotang

The interconnection between two different religious groups will possibly cause conflict and clash as well as peace and cooperation with each other. The case of religion conflict can be seen, for instance, in the interconnection of Muslims and Christians in several countries; e.g. in Europe and America, Muslims and Hindus in India, Muslims and Buddhists in Thailand, and Muslims and Christians in Philippine. The cases of clash and conflict between some Muslims and some Christian have happened in some places throughout Indonesia. Unlike the aforementioned conflict and clash cases between some Muslims and some Christians, the relation between Muslims and the Hindus of Towani Tolotang in Amparita village shows the opposite. The Muslims and Hindus have an excellent relationship because they are aware of the importance of honesty and togetherness among them. In fact, the two different religious groups run their daily life handin hand and in a friendly manner. The honesty and togetherness are important points for them to maintain their relationship in order to resolve their differences (Jubba 2016).

\footnotetext{
${ }^{1}$ Hasse Jubba* (corresponding author), Ph.D., lecturer at Doctorate Program of Islamic Politics-Political Science, Graduate Program, Universitas Muhammadiyah Yogyakarta, Jl. Brawijaya Tamantirto, Kasihan, Bantul, YOGYAKARTA, Indonesia, email: hasse@umy.ac.id; Mustaqim Pabbajah, Ph.D., lecturer at Faculty of Humanities, Education and Tourism, University of Technology, YOGYAKARTA, Indonesia, email: mustaqim_pabbajah@uty.ac.id; Zaenuddin H Prasodjo, Ph.D., lecturer at State of Islamic Institute, PONTIANAK, Indonesia, email: zaestain@yahoo.com; Zuli Qodir, Ph.D., lecturer at Doctorate Program of Islamic Politics-Political Science, Graduate Program, Universitas Muhammadiyah, YOGYAKARTA, Indonesia, email: zuli_qodir@yahoo.com.
} 
From the literature review on the topic of relations among the different religious groups, the previous researchers tend to examine three different areas; firstly, they investigated the connection and relationship among the different religious groups in terms of the majority and minority (Latif 2012; Migheli 2016; Ruane 2006). In addition, the studies investigated the issues of hegemonic and domination of relations among the different religious groups. Such pattern of relationship is always come into practiced by Indonesian in a plural society. Secondly, the previous studies investigated the differences of religious doctrines as the sources of conflict in the society (Pamungkas 2014; Wasino 2013; Wibisono 2017). In this kind of research has found the different religious doctrines are claimed to be one of the factors causing some tense moment in any different religious society. Thirdly, the previous studies looked into the possibility of further impacts of religious interconnections, including the existence of new religious doctrines and synergy among religious groups (Haddad \& Fischbach 2015; Ramli 2015; Suciati 2015). They committed and dedicated to make new agreements in building reciprocal relationships between different religious groups and doctrines. The present article focuses on the issues of how to maintain the sustainability of the different religious groups and their relations in facing the challenges in the future.

Furthermore, this article explores three important issues; firstly, it examines how Bugis Muslims and Bugis Hindus of Towani Tolotang in Amparita commit themselves to practicing their togetherness. It concerns about the existence of Bugis Muslims and Bugis Hindus of Towani Tolotang who have different beliefs and commit to practicing their own beliefs in the society. Secondly, it determines supporting and non-supporting factors for the realization of community unity between these two different religious groups. It concerns about the possibility of conflict between these two religions along with the dynamics of the social life. Thirdly, it investigates the plans and actions of these two different religious groups to maintain the harmonious life among them. It concerns about identification and strategy choices conducted by these two different religious groups to maintain their good relationship. These research issues will be operationally explained answered in this article.

The present study is based on three basic assumptions: the first of them is the harmonious life between Bugis Muslims and Bugis Hindus of Towani Tolotang in Amparita has existed naturally and dynamically. Although they have different religious beliefs, they have committed to live in a harmonious life. The second is the similarity of the cultural background is one of the important aspects to maintain their togetherness. Furthermore, they have a strong commitment to build a peaceful life among them in the society. Third assumption is achieving an equal status and deserving the same right as an individual or a person is a strategic way to maintain their togetherness. These efforts are focusing on how these two different religious groups have the same right and treatment, including their status in the society.

\section{The Relations between the Majority-Minority Groups}

Humans as social beings wish to have an intensive interaction with other people. The existence of such interactions either directly and indirectly may or may not lead to conflict of interest or strengthening the identity of a community over others. According to Latif (2012), the religious groups succeed in the process of strengthening their identity because of social support, due to their quantity and quality, tend to claim themselves as the majority groups, as a result, the minority groups will be considered as the 'second-class' that are under the influence of majority groups. In several dimensions of social life, the majority groups usually ignore the productivity aspects of the minority groups. In a pluralistic society, the existence of majority and minority groups is often always associated with a source of conflict because of the prejudices that develop among them.

Religion is said to be the source of most of the conflicts between the majority and minority groups (Migheli 2016; Ruane 2006). The religious identity can influence individual perceptions 
and cause changes in behaviour responses in social interactions (Gupta et al, 2018). This is in line with a study conducted by Eisenberg et. al. (2009). They found out that there have been tensions between the Muslim and Christian groups in Indonesia in the past few decades leading to the Muslim groups increased their compliance with their traditions (e.g. Muslim women covering their heads). Meanwhile, Kanas et. al. (2016) found out the Muslims and Christians in Ambon's conflicts were caused by a higher level of politicization because Muslims who were in a lower average of socio-economic status than the Christians and therefore the Muslims in Ambon became the minority on the regional scale. Historically, the violent behaviours have caused hatred between the Christians and Muslims since hundreds of years ago because of the marginalization of Muslims during the Dutch colonial period and subsequently the marginalization of Christians during the New Order political leadership era in Indonesia.

\section{The Relations between the Newcomers and the Indigenous People}

The newcomers are the immigrants in this article. Human migration has become a main topic in many European countries (and around the world), not only because of the movements of refugees but also following the process of European integration and globalization. According to Pratsinakis (2017), an understanding of who will be a part of the nation, who can be a member and under what conditions, and who will be excluded, and their understanding are very important in order to comprehend the power dynamics of the underlying the immigrant-indigenous relations. In sociological point of view, the relations between the immigrants and the indigenous people traditionally have been conceptualized as a problem of cultural adaptation (Pratsinakis 2013). Meanwhile, according to Bourhis et al (Goedert et. al. 2019), the indigenous people can choose between friendly reception (e.g. integration) and unfriendly acculturation orientation (e.g. assimilation, segregation, and exclusivity) in expressing how the immigrants must behave in the view of the indigenous people. The friendly reception is characterized by a tolerance for diversity and cultural diversity that allows the immigrants to culturally stay connected with their home countries and to establish contacts with the local communities and vice versa. The unfriendly acculturation orientation is either excluding the immigrants from local communities or urging them to completely ignore their original cultures.

According to Berry, Kalin, and Taylor (Goedert et. al. 2019), a person who feels comfortable culturally and economically is most likely open-minded and tolerant towards other cultures and he has more positive attitudes towards the cultural diversities and multiculturalism. This multiculturalism hypothesis has been widely examined by Berry et al, and it shows that the feelings of the indigenous people about economic or cultural threats due to the arrivals or presences of the immigrants can be a source of negative attitudes towards the cultural diversity, lacking of the openness to the immigrants, and the indigenous people are reluctant to change their cultural aspects due to their cultural contacts with the immigrants or the newcomers into their countries and communities.

In fact, some of the literatures show that the relations between the indigenous people and the immigrants are less harmonious, for instance, a study conducted by Ehrkamp (2006) in Germany with Turkish immigrants' respondents where the Germans urged the Muslims from Turkey in Germany to assimilate with the German culture and norms. In 1996, the Muslim community in several neighbourhoods of Duisburg (led by the Diyanet Mosque community of Marxloh) had tried to get approval from the city government to broadcast a call for Friday prayer through loudspeakers. On the other hand, the proposal was seen as an effort to the way of 'Islamization' of Germany. As a result, the protests had been made by public against the proposal and it was published nationally in the newspapers, the magazines and the television shows.

Such assimilation discourse has not only caused the immigrants as 'liyan', but also made the Germans in Germany more strength and dominant. The study conducted by Pratsinakis (2013) on the immigrants and the indigenous relations in Thessaloniki, Greece was in line with 
Ehrkamp's research (2006). The research results showed that they had not only cultural relations but also the configuration of power taking place through symbolic contestation about defining the nation and who belongs to the nation of Greece. The Greek state policy is closely related to the nation's self-perception as a community determined by its descent. According to this perception, non-Greek immigrants who entered and stayed for a long time were seen as a threat to social cohesion and the homogeneity of national culture. The indigenous people maintained their position because of their ability to present themselves as the norms that the immigrants must comply with their rules. Thus, they viewed the immigrants as the candidates for the nation members and they asked the immigrants to prove their ownership by proving the 'practical citizenship' accordingly.

\section{The Research Method}

This article is based on the findings from our research conducted in 2017 and 2018 in Amparita, the Regency of Sidenreng Rappang. Our research methods were the interviews and observations of selected respondents among the Muslim and Hindu religious groups in Amparita. We selected our respondents purposively and conveniently to collect the needed data and information from the selected respondents in this study.

Amparita is a village or hamlet in Tellu Limpoe Sub-district. Sidenreng Rappang Regency is an area occupied by two different religious groups with their number of populations is a relatively balanced. This village is in the middle of the township district where social activities are very dynamic. There are some facilities provided such as markets, schools, offices, community health centres, sports facilities, and other public facilities including worship facilities such as mosques and musalla. Meanwhile, the worship facilities for Towani Tolotang were not found, except a place to conduct the annual ritual, namely Perrinyameng, a place of the ancestral tomb, which is located close to the village of Amparita.

The primary data used in the present study were obtained from several resources; books, scientific journals and other written documents that have been previously written by several experts. Data from the literatures are processed and mapped based on the needed analyses. Furthermore, data on the population based on the religious groups were gained from the Population and Civil Registration Agency (Kantor Kependudukan dan Catatan Sipil) of Sidenreng Rappang District. The population data used was of 2017 data because that was the latest available data. The descriptive-discursive analyses were utilized in the present study. It is aimed at explaining the main issues discussed and comparing several cases regarding the relations of the majority and minority religious groups in several places. In addition, the historical perspective was also used to review the relations of Towani Tolotang and its association with the Bugis Muslim groups in Amparita.

The majority group in this article is referring to the Muslim group; while the minority group is referring to Towani Tolotang (the Hindu group). This category is used to expedite the identification, especially in the terms used in this study. In fact, the name Towani Tolotang was previously only 'Tolotang'. Furthermore, the name Towani Tolotang has two meanings; one of them refers to the name of a 'religion', and the second meaning refers the community of that religion. Thus, the name Towani Tolotang is referring to these row meanings. In this article, the name is used interchangeably. Therefore, when the authors use "Islam and Towani Tolotang", they refer to the two different religions. When the authors use "Muslims and Towani Tolotang, they refer the two different communities.

\section{The Towani Tolotang: The Minority Groups in the Bugis Society}

The Towani Tolotang is the religious group from outside of Amparita. This religious group was expelled from Kampung Wani in the (kingdom) area of Wajo, an area to the east of Sidenreng 
Rappang Regency. The arrival of Towani Tolotang in Amparita was firstly rejected by the indigenous people who were Muslims because Towani Tolotang had different beliefs from the Muslims in Amparita. However, the local authority (addatuang) of Amparita accommodated Towani Tolotang by allowing them to live in the southern part of Amparita. Thus, the terms Towani Tolotang mean that the persons from Wani (Towani) who live in the southern part of Amparita (Lotang). They have lived in the southern part of Amparita village. This name has existed until the present time. This name has two meanings, first, it refers to people who live in the South of (Amparita Market), it also refers to the religious group (community). The term Towani Tolotang or Tolotang was first used by Addatuang to communicate with the newcomers in Amparita (Jubba 2016).

The groups of Towani Tolotang can be found in Amparita or in Sidenreng Rappang Regency and in other areas in South Sulawesi such as in Wajo, Pinrang, Enrekang, Pare-pare, and in some areas outside the regencies. In fact, the Towani Tolotang population is the largest in the Sidenreng Rappang District compared to other districts. In this district, Towani Tolotang is the second largest population after Muslims. The information about the population of Towani Tolotang in Sidenreng Rappang Regency can be seen in the following Chart.

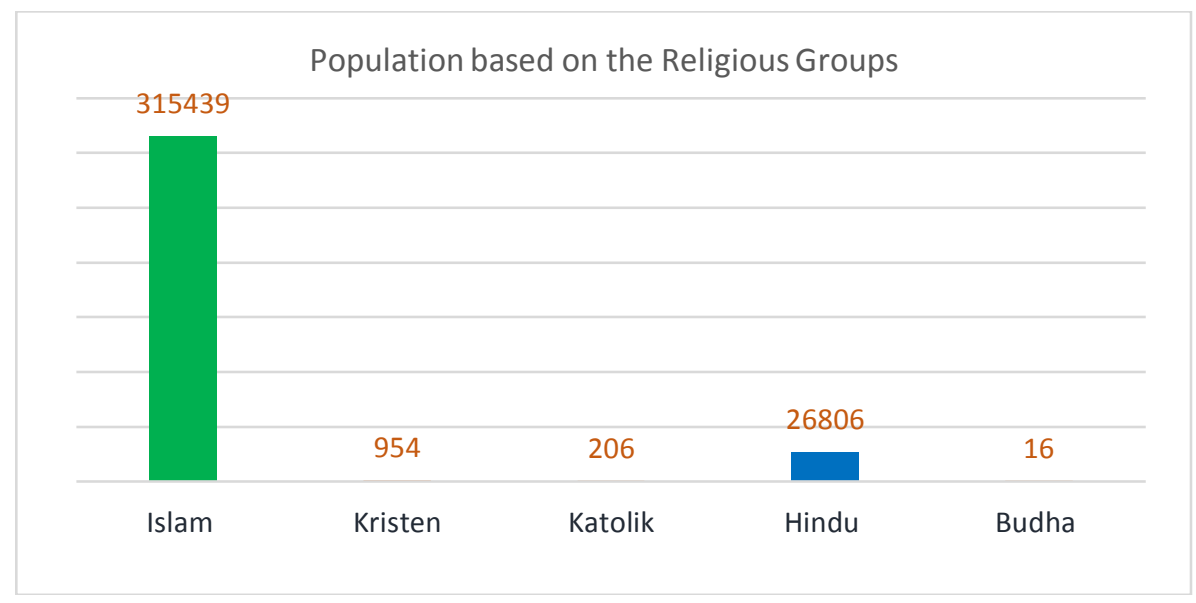

Data Source: Population and Civil Registration Agency Sidenreng Rappang, 2017

From Chart 1, it is clearly seen that Towani Tolotang has their followers in the amount of 26.806 people or $7.8 \%$ of the total population or population in Sidenreng Rappang Regency (343,423 people in 2017). The majority of the population is Islam with the number of populations is about 315,439 people, or $91,85 \%$, while Christianity's (Kristen) is about 954 people or $0.2 \%$, Catholics' (Katolik) is about 206 people or 0.05, and Buddha's (Budha) population is about 16 people or $0.004 \%$.

\section{The Portrait of Muslim and Towani Tolotang Religious Social Life}

The initial interconnection of Islam and Towani Tolotang took place in the year of 1666, when Islam was first embraced by the indigenous people in Amparita, Sidenreng Rappang, in South Sulawesi. At the beginning, the existence of Towani Tolotang was rejected by the local community because they had different beliefs. There were a number of rejections from the indigenous people. One of them, for instance, the Towani Tolotang was prohibited to settle down around the village of Amparita. But, the King Sidenreng (the ruler) allowed the Towani Tolotang to live in the southern part of the Amparita village.

Amparita village, or what co-called hamlet, is one of the villages or hamlets that belong to the Tellu Limpoe District of Sidenreng Rappang Regency. At the present time, Amparita is the 
capital of the sub-district and is a business area. This village is the centre of the development of Towani Tolotang; therefore, the elite and community leaders are occupying this village. The Towani Tolotang people have their annual rituals gathering at Amparita at certain period of time. They often visit their leader, called Uwatta or Uwa 'for various purposes such as asking for instructions on the implementation of ceremonies in their life cycle.

The Towani Tolotang in Amparita is now always living in a harmonious life and side by side with the Muslims. They live closely to each other and have an equal treatment without any discrimination in terms of the neighbourhood system, house construction, and others. The Muslims and Towani Tolotang people meet and interact with each other every single day both in residential areas and in public places such as in schools, markets, fields, hospitals, and elsewhere. The professions of these two different religious groups are mostly farmers, and therefore, they often have chances to meet in their neighbourhood and in the rice fields. The topic of discussion is not related to the religious doctrines, but more on the issues of their lands, e.g. the land is being cultivated, the prices of fertilizers, production costs, and so on, so forth. Up to now, it is very common to see they help each other to carry out their works in their fields. The rice cultivation is now using modern equipment's; the tractor machines are used to plough the fields in lieu of the animals, a traditional rice cultivation method. Although there is business oriented in their activities, but they are still committed to supporting each other by providing them with meals and beverages when there are functioning together.

The other examples of best practices performed by the two different religious groups are when they are building houses, especially the wooden houses of Bugis ethnic or tribe, the helpers are mostly free of charge, but the meals and beverages are provided for them during the day. Only the skilled workers and their assistants are paid for their job. In fact, it takes a long period of time to build a house, therefore, the helpers are sometimes present and sometimes they are absent because they are busy doing their own businesses. Another example of the best practice is when they are building a mosque. The Towani Tolotang always wanted to take a part in building a mosque. The Muslim groups welcome them to help and have no objection to the Towani Tolotang's participation. It is evidence that these people are aware of the importance of togetherness. Next, when they have any problem, these two religious groups always help each other, for instance, when they have the death of a family, the two groups welcome each other without seeing their religious background. Indeed, they are bound by the social life system and has no objection on their religious differences for their mutual needs.

Since the position of their houses is very close to each other, then they have a high frequency of meetings, and therefore they too have an open relationship to both religious groups. The sympathetic relationship between the two groups, for instance, can be seen during the month of Ramadan where Muslims perform various religious activities during the day and night. Having had the religious activities, the Towani Tolotang people who live around the mosque have no objection to the religious activities of Muslims carried out at the mosque, including the use of loudspeakers during the day and night. During the tarawih prayer, for instance, there was a preacher who delivered the religious speech in the mosque, and the Towani Tolotang people do not mind at all although they might annoy by the sound of the loudspeakers. Besides, the topics of the Islamic religious lectures never cause harms to other people or groups.

In general, the themes addressed by the Muslim religious preachers are closely related to social practices and daily life issues, including how to build-up a good and productive social relationship such as fostering mutual respect, and mutual assistance. In fact, the Towani Tolotang' youth group was assigned to safeguard at the mosque when the worship is performed. Meanwhile, the Muslim groups have also no objection to the annual ceremony of the Towani Tolotang to honour and respect for their ancestors. The Towani Tolotang people have ceremonial and devotional visits to the graves of their ancestors in January every year in Amparita. They come in groups from several areas and the crowded gathering moment may cause the traffic jam and annoy the local people. But the Towani Tolotang people were still warmly welcomed by the 
Muslim groups and together with the police officers, they were safeguarding the Towani Tolotang people as their guests in a friendly manner.

There are three important points that we would like to address from the discourse. The first one is a mutual understanding between the Towani Tolotang and Muslim people at any time, and nothing to do with the religion. This is one strong indicator that they would like to live side by side in a harmoniously way. The second point is the involvements of these two different religious groups in an event can be seen not only as the acceptance of the verbal communications between them, but also as the real social practices among them. The third point is the intensity of the meetings between the Towani Tolotang and Muslim people indirectly affected the choice of the communication model between the two religious' groups. Therefore, the successful of building relationships and good communication make it possible for them to achieve a more humanistic life and more tolerant to their differences.

\section{The Cultural Similarity: A Call for Unity of the Two Groups Relations}

When the king of Wajo officially announced Islam became the religion of the royal ruling families and for all the people in his teritory, the Towani Tolotang had objection and they refused to be Muslims. Therefore, they must have to leave the kingdom of Wajo immediately. Then, they moved to the kingdom of Sidenreng area, especially in Amparita village. At the beginning, their presence was rejected by the indigenous people of Amparita because they have different religious beliefs. In fact, Islam was accepted by the kingdom of Sidenreng one year earlier than the Kingdom of Wajo. The Muslims who were the indigenous people in Amparita objected the arrival of the Towani Tolotang in their village. They reported their objection to their king (Addatuang). The king of the kingdom provided a final solution to the problem between the indigenous Muslims and the Towani Tolotang, the newcomers the village and the king ordered the Towani Tolotang to stay and live in the southern part of Amparita village. Since then, they have been there occupying the land areas provided by the king to them and establishing their lives until the present time.

Having the strong cultural commitments have made it possible for the Towani Tolotang people and Muslims in Amparita to live side by side in the society. These two different religious groups are from the Bugis ethnics who still maintain their customs and values, especially in establishing their social relations. The Bugis ethnics follow the values as dictated and requested by Pengadereng. Therefore, they keep practicing those values in their daily lives. The equality of right or what so-called Sipakatau is a good example of the values accepted and practiced by these two different religious groups. The basic concept of this value is to respect all people regardless of their ethnic, racial, religious, class, and gender differences (Hadis Badewi 2016; Mustadjar \& Dirawan 2017). This concept emphasizes the importance of mutual respect for human beings as stipulated by the main concept of Sipakatau. In this phase, the cultural adaptation is performed in order to facilitate the contact of the two groups of cultural integration (Pratsinakis 2013).

Practicing different religious beliefs does not make the Towani Tolotang group oppose to the majority group. In fact, the Towani Tolotang group always feels safe although they are the minority in the society. They never claim that their beliefs are right, and others are wrong. The same thing also happens to the Muslim group; the Muslims never compare and contrast the differences of their own religion with the other religions. In the Ramadan and on Fridays, for example, the Muslim preachers never claim that their beliefs are right and other are wrong because it might lead them into a serious social conflict with the other religious adherents. The Mappenre 'nanre ritual, one of the Towani Tolotang's rituals, is to thank for the good fortune among them. It is also used as a medium to internalize the values, and to address the moral cohesion to the members in their group. Furthermore, the leaders of Towani Tolotang urge their people, for instance not to do wrong, never hurt others, and to comply with all the Towani 
Tolotang's teachings. This ritual is carried out regularly at the houses of the community leaders and the Muslims have no objection to their ritual activities.

There is an oral message from the Muslim leaders that "the non-Muslims are not allowed to live in the Sidenreng Rappang" This oral message still exists up to the present time. In fact, none of the families embraced Christianity in this area. So, the verbal message of the non-Muslims refers to the Christians only. Meanwhile, the Towani Tolotang is not categorized into the nonMuslims because they have settled down in this area for a long period of time. In addition, the Towani Tolotang people have been actively involved in the politics during the Reformation Era by being the Speakers of House of Representative (DPRD) from several different political parties in the Sidenreng Rappang District. Their involvement in the politics have made them possible to contribute to the regional development.

The relationships between the two different religious groups show three significant indicators. Firstly, there is a pattern of relations that urging and encouraging them to live in a harmonious life between the Towani Tolotang and the Muslims in Amparita. Both religious groups "ignore" their religious identities in the dynamics of social life. Secondly, the Towani Tolotang and the Muslims pay more attention on their spirit of equality rather than on their differences. Hence, they have committed to having social life: being very cooperative and avoiding big controversies over the differences in the community. Both religious groups have committed to practicing moral values that are still respected by the Bugis people in Amparita. Thirdly, the differences in the religious beliefs have been reduced by the cultural similarities of the Bugis people. The two different religious groups have succeeded in managing their good relationships by paying less attention to their religious differences.

\section{The Construction of Society Residential Status: the Towani Tolotang as a Migrant}

Apart from the supporting factors in making the Towani Tolotang and Muslims be together, there are also factors that might ruin their good relationships. For instance, since the Towani Tolotang group is the migrated population, and if they were treated unfairly and differently in the community, the unfairness would generate the 'hatred' among the Towani Tolotang. In fact, historically speaking the religious conflicts took place forcing the Towani Tolotang into converting to Islam in the past. However, some of the Towani Tolotang people had not converted to Islam; they remain as the Hindus.

Due to the Towani Tolotang' status as the newcomers in Amparita, their relations with the Muslims are sometimes up and sometimes down. In addition, the terms Towani Tolotang contain discriminatory claims. The Tolotang is derived from two syllables; to (people) and lotang (close to/southern part). For the Bugis ethnics, it refers to something specific and usually has negative connotations. The meaning of Tolotang (people who live in the Southern part) has the same meaning when the Bugis people use the word 'color' as initials for someones' name, for instance, Tobolong (bolong i.e. black) means black people. This situation might cause conflict between the two groups and can ruin the harmonious living condition that has been achieved over period of time. The implication of the terminology can lead to a negative stigma, for instance, when the Towani Tolotang is called as a 'second class' community. This situation could trigger new tensions in the community as the Towani Tolotang could recall their bad experience of being rejected from Amparita community long time ago.

Apart from being a second-class community, the Towani Tolotang is also considered as the 'opponents'. This stigma is based on the historical arguments that the Towani Tolotang was expelled from Wani village in Wajo because of their rejection of being Muslims, the religion of the kingdom of Wajo after its king embraced Islam. Instead of choosing Islam as the majority groups in Amparita, the Towani Tolotang has chosen Hinduism as their religion. This stigma will only worsen the situation and may cause disastrous impact for their future relations. The unequal status in the society may also cause inclusive attitudes among these two different religious 
groups. This will potentially continue to be a trigger for new tensions that will separate them from their basic culture. In fact, the Towani Tolotang and Muslim groups are the Bugis people who have been committed to improving their brotherhood and equality based on the Bugis inherited and shared values.

\section{The Implementation of Local Wise Values to Support the Equality}

In a multi-cultural society like in Indonesia, the issue of relationship between the majority and minority groups often triggers the tensions in their community (Ni'am 2008; Pamungkas 2014; Tirtosudarmo 2018). The majority groups usually have the opportunity to access widely to various facilities (e.g. public facilities), while the minority groups will be overlooked in their rights. As a result, there are unequal treatments between the majority and minority groups, especially among the religious groups. The unequal treatments can turn into new tensions between the majority and minority religious groups. In fact, Islam and the Towani Tolotang are two different religions in nature, and the majority-minority issue still exists between these two different religions where Islam is the religion of the majority group and the Towani Tolotang is the religion of the minority group.

The Towani Tolotang and the Muslims have shared the same cultural values, and they both have the same cultural guidelines. They will always place tradition rule 'adat' as an important element in their social relations. In fact, in a certain situation, the cultural values are more powerful than the religious doctrines. This can be seen, for instance, in the rituals of the life cycle of the Bugis people which are very much influenced by the teaching of their ancestors than their religious teachings. In the concept of pangadereng (Jumadi 2018) there are five main elements of guidance; they are adeq, bicara, wari, and rapang, then sarak (Islamic religion). It is clearly seen that the sarak or religious value is the core values of the Bugis people.

The practical values which are performed by the Bugis people to support the continuity of social relations are based on the Pangadereng. The spirit of Sipakatau (using the sign) for instance, is an effort to humanize the persons or individuals (Amin et al. 2015; Jubba, Rustan \& Juhansar 2018). This means that all humans have the same rights and obligations. This value is still very strongly held among the Bugis people as seen in the practice of social life between the Towani Tolotang and the Muslims in Amparita. In fact, Pangadereng is part of character education (Nurnaningsih 2018) where the values of togetherness and equality are a must.

It is not surprise that if one certain family in Amparita has the family members of different religions. In fact, the Towani Tolotang people converted into Islam because they married to the Muslims. Therefore, when their Muslim family members celebrate the Muslim festivals such as the Eid al-Fitr, the Towani Tolotang people visit their Muslim relatives who can be their own sons or daughters. The same thing happens when there is an 'open house' among the Towani Tolotang family members, the Muslims visit their relatives who can be their own sons or daughters among the Towani Tolotang families. It is evidence that they share the mutual understanding to respect each other although their religions are different.

The acceptance of the people of the Towani Tolotang in the politics in Amparita can be an indicator that they are fully welcomed by other religious groups in their localities. In fact, in the 2014 legislative elections, three Towani Tolotang individuals were successfully elected as the Member of House of Representative (DPRD) of the Sidenreng Rappang. Therefore, the access to politics is not only for the majority groups, but also for the minority ones. Furthermore, in 2019, several people from the Towani Tolotang were also elected as members of the Member of House of Representative. This is evidence that they have equal access and opportunity to actively participated in the politics although they are the majority group.

To conclude, apart from having a dynamic and harmonious relationship, the interconnections of different religious groups tend to sometimes cause conflicts. However, the Muslim and theTowani Tolotang groups are committed to providing a great opportunity to 
establish the peaceful and harmonious relationships by following the very strict wise guidelines based on the Bugis inherited and shared customary wisdoms.

The Muslim and the Towani Tolotang groups have the fundamental similarities in cultural values although they have different religions. This similarity provides the space and opportunity for them to cooperate and communicate and to deal with their different religions. The relationship which has been established between these two different religious groups has created a new pattern of communication and high commitment to respect the Bugis indigenous and inherited values that have existed in these two different religious groups based on the Bugis customary values and wisdoms.

The Towani Tolotang people sometimes have problems with the indigenous Muslims in Amparita because they are considered as the newcomers or the immigrants. This stigma may create new tensions and ruin their relationship with the majority group. Historically, they are not the indigenous people of Amparita, but they have a great contribution and have high commitment to live together in peaceful coexistence with the majority indigenous group. However, the relation pattern based on the migrant and indigenous groups is not so comfortable on the lower level of trust between the majority and minority groups of different religions. This is one of the problems that can change the direction of communication pattern from open into closed communication due to some prejudices. However, the Muslim and the Towani Tolotang groups have made great efforts to eliminate some prejudices among them by not promoting the right and the wrong of the religious beliefs among them.

The mutual commitments between the different religious groups will determine the future relations of the majority-minority religious groups in Indonesia. These commitments are needed to accommodate the existence of the different religious groups in the same localities. The majority and minority individuals sometimes show their egocentric attitudes about what they wish. The real challenge is how to build a harmonious life, and to have an honesty relation, as well as mutual respect for the pluralistic community. In addition, the challenge of the strategy is to build the relationships that are more open, harmonious, mutual benefit and mutual respect in this pluralistic society. To achieve these conditions, they must have a strong commitment to live side by side, to compromise or tolerate their differences even though they are religiously different by giving their priorities to the equality and the harmonious and peaceful life conditions in Amparita.

\section{References}

Amin, K. F. et al. 2015. The ideology of Buginese in Indonesia: study of culture and local wisdom. Journal of Language Teaching and Research 6(4): 758-765.

Ehrkamp, P. 2006. We Turks are no Germans: assimilation discourses and the dialectical construction of identities in Germany. Environment and Planning 38(9): 1673-1692.

Eisenberg, N., Sallquist, J., French, D. C., Purwono, U., Suryanti, T. A., \& Pidada, S. 2009. The relations of majority-minority group status and having another-religion friend to Indonesian youths' socioemotional functioning. Developmental Psychology 45(1): 248259.

Goedert, C., Albert, I., Barros, S., \& Ferring, D. 2019. Welcome or not? Natives' security feelings, attachment and attitudes toward acculturation of immigrants. International Journal of Intercultural Relations 69: 24-31.

Gupta, G., Mahmud, M., Maitra, P., Mitra, S., \& Neelim, A. 2018. Religion, minority status and trust: evidence from a field experiment. Journal of Economic Behaviour \& Organization. 146: 180-205.

Haddad, Y. Y. and Fischbach, R. 2015. Interfaith dialogue in Lebanon: between a power balancing act and theological encounters. Islam and Christian-Muslim Relations 26(4): 423-442.

Hadis Badewi, M. 2016. Relasi antarmanusia dalam nilai-nilai budaya Bugis: perspektif filsafat dialogis Martin Buber. Jurnal Filsafat 25(1): 75-99. 
Jubba, Hasse. 2016. Dinamika hubungan Islam dan agama lokal di Indonesia: pengalaman Towani Tolotang di Sulawesi Selatan. Wawasan: Jurnal Ilmiah Agama dan Sosial Budaya 1(2): 179186.

Jubba, Hasse, Ahmad Sultra Rustan, and Juhansar Juhansar. 2018. Kompromi Islam dan adat pada praktik keagamaan Muslim Bugis di Sulawesi Selatan. JSW: Jurnal Sosiologi Walisongo 2(2): 137-148.

Jumadi. 2018. Lontarak Latoa salah satu sumber informasi tentang hukum bagi masyarakat Bugis. Jurisprudentie: Jurusan Ilmu Hukum Fakultas Syariah dan Hukum 5(1): 115-123.

Kanas, A., \& Martinovic, B. 2016. Political action in conflict and nonconflict regions in Indonesia: the role of religious and national identifications. Political Psychology 38(2): 209-225.

Latif, Syarifudin. 2012. Meretas hubungan mayoritas-minoritas dalam perspektif nilai Bugis. Jurnal Al-Ulum 12(1): 97-116.

Migheli, M. 2016. Minority religious groups and life satisfaction in India. Australian Economic Review 49(2): 117-135.

Mustadjar, M. and Dirawan, G. D. 2017. Gender perspective in Bugis Makassar. Advances in Social Science, Education and Humanities Research 149: 52-54.

Ni'am, H. 2008. Utilitarianism: history, concepts and roles. Jurnal Ilmu Politik Hubungan Internasional 5(2): 98-108.

Nurnaningsih, N. 2018. Pendidikan kepribadian dalam Pangadereng: naskah Latoa asimilasi dengan nilai-nilai Islam. Lentera Pendidikan : Jurnal Ilmu Tarbiyah dan Keguruan 18(1): 43-55.

Pamungkas, Cahyo. 2014. Agama, etnisitas, dan perubahan politik di Maluku: refleksi teoretik dan historis. Masyarakat Indonesia 40(1): 37-56.

Pratsinakis, M. 2013. Resistance and compliance in immigrant-native figurations: Albanian and Soviet Greek immigrants and their interaction with Greek society. Journal of Ethnic and Migration Studies 40(8): 1295-1313.

Pratsinakis, M. 2017. Established and outsider nationals: immigrant-native relations and the everyday politics of national belonging. Ethnicities 18(1): 3-22.

Ramli. 2015. Agama dan kehidupan manusia. Jurnal Pendidikan Ilmu-ilmu Sosial 7(2): 138-144.

Ruane, J. 2006. Majority-minority conflicts and their resolution: protestant minorities in France and in Ireland. Nationalism and Ethnic Politics 12(3-4): 509-532.

Suciati, S. 2015. The cohesiveness of Muslim Pangestu members in Salatiga, Central Java. AlJami'ah: Journal of Islamic Studies 52(1): 85-99.

Tirtosudarmo, Riwanto. 2018. Migration, Ethnicity and Conflict in Southeast Asia. In: The Politics of Migration in Indonesia and Beyond. Singapore: Springer.

Wasino. 2013. Indonesia: from pluralism to multiculturalism. Paramita 32(2): 148-155.

Wibisono, M. Yusuf. 2017. Agama, kekerasan dan pluralisme dalam Islam. Kalam 9(2): 187-214. 